\title{
Integrated Cooling Tower for Fertilizer Complex a New Approach
}

\author{
Prem Baboo \\ DGM (Production \& Process)
}

\begin{abstract}
The objective of this study is to investigate experimentally and theoretically heat and mass transfer characteristics of the common cooling tower for world largest Fertilizers complex and Induced cooling system is also world largest cooling Tower. This theory is universally adopted for calculations of cooling tower performance. Detail of these design parameters and other characteristics of manufactured cooling tower are mentioned in design methodology section. Effectiveness of $55 \%$ to $85 \%$ was obtained from experiments. Cooling tower process is generally related with vapour pressure of water and humidity. Cooling tower sizing can simply be done by graphical methods. Some additional calculation such as water make-up, fan horsepower calculations are also explained in this article. Sources of error include increase in humidity of surrounding air after one complete trial, the area near Atlantic Ocean hence humidity changed frequently. Due to this air becomes saturated and becomes a cause of decrease in effectiveness. Drift losses are also a cause of error in experimental results. Cooling towers are heat removal devices used to transfer process waste heat to the atmosphere. These cooling towers are found at really big dimensions at Dangote Fertilizers plants. The primary use of large, industrial cooling towers is to remove the heat absorbed in the circulating cooling water systems used in Dangote Fertilizer Train -1 \& Train-2 Ammonia, Urea and Granulation with common utilities plants. These things have to be so big to be able to cool the water in a constant rate. The Cooling water system is provided mainly for ammonia and urea process cooling requirements and for relevant auxiliary systems, based on evaporative cooling cells of conditioned water routed to the users and then returned to the cooling towers for restoring the proper temperature before being recycled to the users. It can be concluded that proper packing, shut down strategy and water distribution are important for optimization of cooling towers. It is important to identify such factors and optimize these for efficient working of cooling towers.
\end{abstract}

Key Words:- ID Fans, Cooling water pumps, wet bulb, dry bulb, range, approach, Heat transfer, mass transfer.

\section{INTRODUCTION}

The Dangote Fertilizer project consists in the realization of an Ammonia and Urea complex with associated facilities. The projects have set up at Lekki free trade zone in Ibeju-Lekki Local Government Area of Lagos State. The Dangote group is a Nigerian multinational industrial conglomerate, founded by Aliko Dangote. It is the Largest Conglomerate in the West Africa and one of the largest in the African Continent.Ammonia and Urea complex includes:

Ammonia and Urea complex process plants include:

2 x 2200 MTPD Ammonia Train based on HTA Technology.

2 x 3850 MTPD melt Urea Train based on Saipem Technology

2 x 3850mtpd Urea Granulation Train based on UHDE Fertilizer Technology

Associated utility units (common to both Ammonia- Urea - Granulation Trains) SAIPEM, Italy is the Engineering, Procurement and Construction (EPC) contractor for the Dangote Fertilizer Project. Under contractual obligation, SAIPEM has to transfer the technology of Ammonia, Urea and Granulations to Dangote Fertilizer Limited under license agreement with Haldor Topsoe, Denmark, Saipem, Italy and UHDE Germany respectively. SAIPEM is carrying out the supervision for construction \& precommissioning and commissioning under the contract signed between Dangote Fertilizer Limited and SAIPEM with technical manpower support provided by DFL after the SAIPEM handover plant to DFL, all operational activities have performed by DFL.

\section{BRIEF DESCRIPTION OF COOLING TOWER}

Cooling water system is provided mainly for ammonia and urea process cooling requirements and for relevant auxiliary systems, based on evaporative cooling cells of conditioned water routed to the users and then returned to the cooling towers for restoring the proper temperature before being recycled to the users. Mechanical draught towers are classified as either "forced draught", where the fan is located in the incoming ambient air stream, or "induced draught" which has the fan situated at the tower exit position to draw the air stream through the tower. Forced draught towers are characterised by high air entrance velocities and low exit velocities, which can make them susceptible to recirculation, giving instability in performance. Induced draught towers have an air discharge velocity of from 3 - 4 times higher than their air entrance velocity, and the location of the fan in the warm air exit stream provides excellent protection against the formulation of ice on the mechanical components. Induced draught towers can be used on installations as small as $5 \mathrm{~m}^{3} / \mathrm{hr}$ and as large as $150000 \mathrm{~m}^{3} / \mathrm{hr}$. Tower types are also classified by airflow. In a counter-flow tower, air flows vertically upwards through the heat transfer medium (plastic fill packing), counter to the downward flow of the water. In a cross flow tower the movement of the air through the fill is across the direction of the waterfall. Each type of tower has distinctly different fan power and pump head energy consuming characteristics. The Dangote cooling tower induced draft cooling tower.

The unit includes the following functional sections: 
1. Cooling Tower Package consists of 22 cells ( 21 in operation plus one spare) $(14 \mathrm{EA} 01 \div \mathrm{A} 21 / \mathrm{B})$ sized to receive a circulation water rate of about $4432 \mathrm{~m}^{3} / \mathrm{h}$ each one. The cells are field erected induced draft, filling film type. As shown in the figure-1

2. Six (6) circulation pumps 14-P-01 A/B/C/D/E/F (five operating and one spare), each one with a rated capacity of $18700 \mathrm{~m} 3 / \mathrm{h}$, are provided to feed the cooling water to the users and to discharge, on flow control, Differential head at rated capacity $=41.3 \mathrm{~m}$, the cooling cells blow down.

3. The sparing philosophy is five cooling water pumps in service and one spare pump in stand-by. In order to maintain CW supply, in case of both low pressure and low flow in the cooling water supply headers, logic 14-D-1 sends a signal to start stand-by pump. Each cooling water circulation pump has one stop check valve at discharge. Stop check valve at stand-by pump discharge is normally closed. When stand-by pump starts, logic 14-D-1 sends a signal to relevant stop check valve in order to open it, with a time delay of $10 \mathrm{sec}$ after stand-by pump start-up.

4. In order to prevent corrosion, scaling and growth of organic matter in the cooling water circuit, a dedicated system of chemical conditioning has been provided. In principle, cooling water conditioning is obtained by the following dosing systems: Chloride Dioxide (14-PK-01), Corrosion inhibitor Phosphate Base (14-PK-02), Anticipant (14-PK-03), Corrosion inhibitor Zinc Base (14-PK-05) \& Secondary Biocide (14-PK-06).

5. One start-up cooling water pump 14-P-02 having a design capacity of $3850 \mathrm{~m} 3 / \mathrm{h}$. This flow rate allows the starting operations of one STG condenser at 50\% load in order to gradually start-up the other cooling water pumps 14-P-01 $\mathrm{A} / \mathrm{B} / \mathrm{C} / \mathrm{D} / \mathrm{E} / \mathrm{F}$.

6. Side stream filtering system (14-PK-04) to keep the content of suspended solids in the Cooling Water Circuit under an acceptable value (not higher than $25 \mathrm{ppm}$ ).

The flow for each plant is tabulated following table No.-1

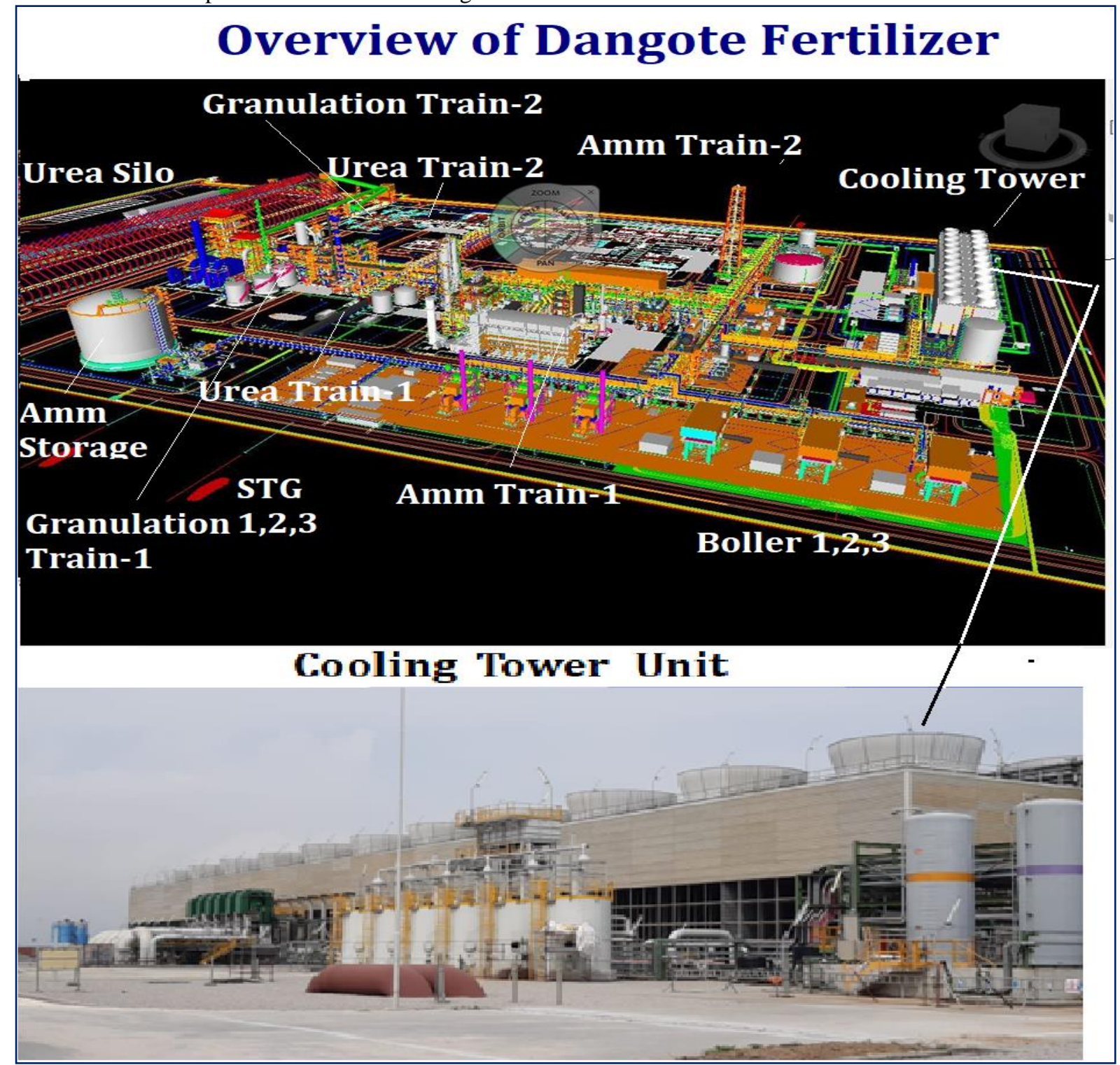

Fig-1 


\begin{tabular}{|l|l|c|}
\hline Sr. No. & Description & $\begin{array}{l}\text { Cooling } \\
\text { consumption, T/hr }\end{array}$ \\
\hline 1 & Urea Plant-Train 1 & 11754.3 \\
\hline 2 & Urea Plant-Train 2 & 11754.3 \\
\hline 3 & Ammonia plant-Train 1 & 20936.8 \\
\hline 4 & Ammonia plant-Train 2 & 20936.8 \\
\hline 5 & Steam \& Power generation system & 18062.1 \\
\hline 6 & Nitrogen Production and Storage system & 20.0 \\
\hline 7 & Instrument and Plant air System & 146.5 \\
\hline 8 & Urea Granulation plant-Train 1 & 11.3 \\
\hline 9 & Urea Granulation plant-Train 2 & 11.3 \\
\hline 10 & Ammonia Plant common area & 847.2 \\
\hline 11 & Urea Plant common area & 6522.0 \\
\hline 12 & Ammonia Storage system & 71.0 \\
\hline 13 & Analyser shelters Total & 10.2 \\
\hline
\end{tabular}

Table-1

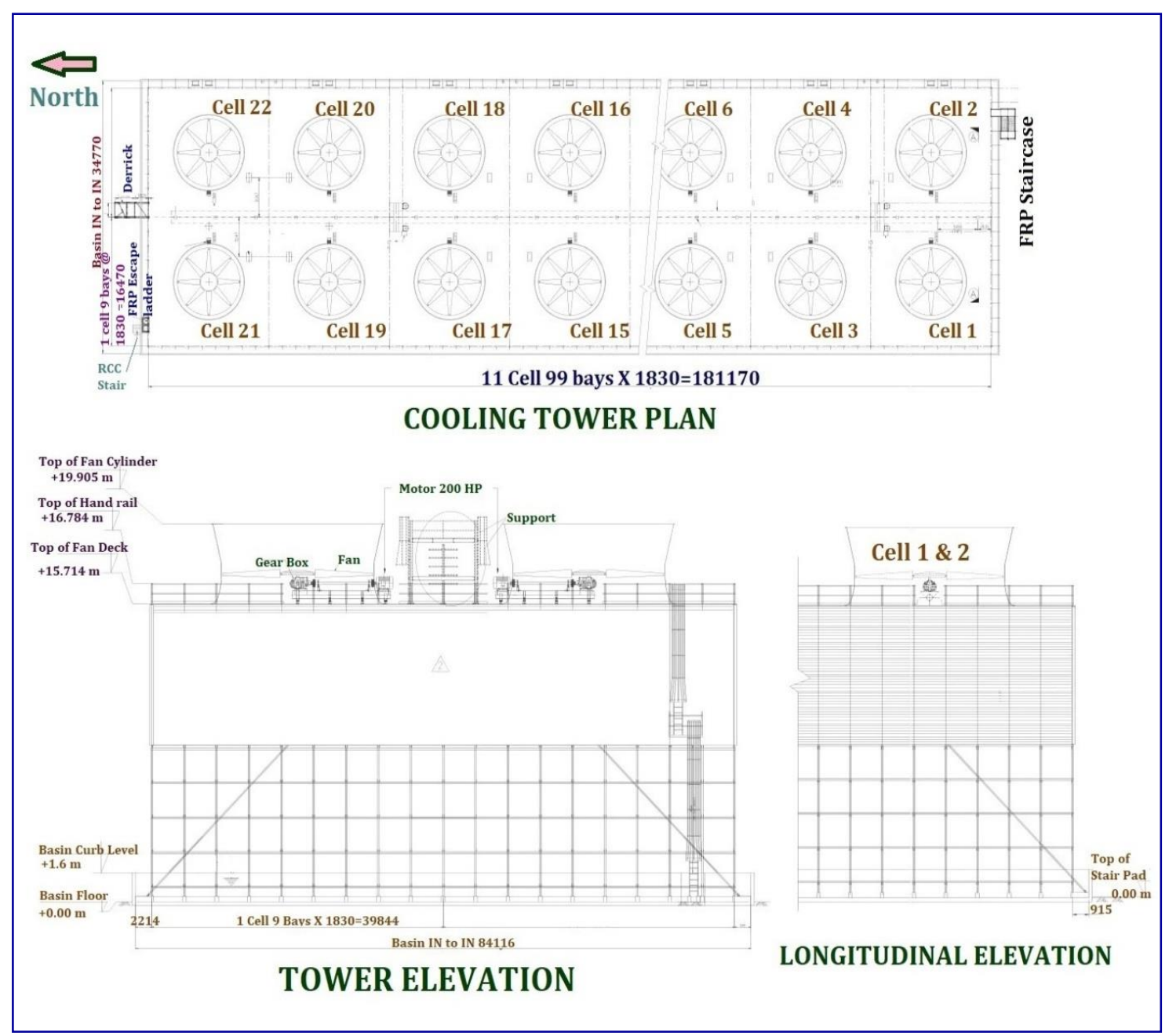

Fig-2

Design Conditions of Cooling Tower

\begin{tabular}{|c|l|l|l|}
\hline Sr. No. & Parameters & Value & Units \\
\hline 1 & Hot water Temperature & 45.4 & ${ }^{0} \mathrm{C}$. \\
\hline 2 & Cold water Temperature & 34 & ${ }^{0} \mathrm{C}$. \\
\hline 3 & Wet bulb Temperature & 29 & ${ }^{0} \mathrm{C}$. \\
\hline 4 & Flow & 93070 & $\mathrm{M}^{3} / \mathrm{hr}$ \\
\hline 5 & Overall cooling surface area & 1596360 & $\mathrm{M}^{2}$ \\
\hline 6 & Cooling Section Height & 1.83 & $\mathrm{~m}$ \\
\hline 7 & Overall cooling section Volume & 10899.95 & $\mathrm{M}^{3}$ \\
\hline 8 & Air inlet surface area & 3000 & $\mathrm{M}^{3}$ \\
\hline 9 & Air outlet surface area & 72.98 & $\mathrm{M}^{2} / \mathrm{cell}$ \\
\hline
\end{tabular}




\begin{tabular}{|l|l|l|l|}
\hline 10 & Air Delivery & 633.7 & $\mathrm{M}^{3} / \mathrm{sec} / \mathrm{cell}$ \\
\hline 11 & C.W.Pump capacity(A to F) & 18700 & $\mathrm{M}^{3} / \mathrm{hr}$ each \\
\hline 12 & Start up C.W. Pump & 3850 & $\mathrm{M}^{3} / \mathrm{hr}$ \\
\hline 13 & C.W. basin capacity & 7792 & $\mathrm{M}^{3}$ \\
\hline 14 & Each cell design Flow rate & 4432 & $\mathrm{M}^{3}$ \\
\hline
\end{tabular}

Table-2

\section{TECHNICAL TERMS OF JUMBO COOLING TOWER}

Cooling rates of Mechanical draft towers depend upon their fan diameter and speed of operation. Since, the mechanical draft cooling towers are much more widely used. Cooling towers might be classified into several types based on the air draft and based on the flow pattern. Each type of cooling tower has its own advantages and disadvantages; thus the proper selection is needed based on the system operation. Besides, the material selection of cooling tower is also important. Cooling towers tends to be corrosive since it always has direct contact with the water. Proper material selection or additional water treatment is then needed to keep the cooling tower safe. The effectiveness of cooling tower depends on flow rates of air and water and water temperature. Minimization of heat loss is one of the important aspects of studies carried out by various investigators. The inter facial area between air and water is also crucial factor in cooling towers. Three types of pickings used in cooling towers are film, splash and film-grid pickings. Also it was observed that drift is one of the important losses in cooling towers. Various shapes of cooling towers are tried by various investigators to study effectiveness. Hyperbolic shape is advantageous due to higher area at bottom. It provides aerodynamics, strength, and stability. The present review is aimed at summarizing studies and research on cooling tower for increasing efficiency and power savings to make it more economical and efficient.Mechanical draft towers Mechanical draft towers are available in the following airflow arrangements: 1. Counter flows induced draft. 2. Counter flow forced draft. 3. Cross flow induced draft. In the counter flow induced draft design, hot water enters at the top, while the air is introduced at the bottom and exits at the top. Both forced and induced draft fans are used. In cross flow induced draft towers, the water enters at the top and passes over the fill. The air, however, is introduced at the side either on one side (single-flow tower) or opposite sides (double-flow tower). An induced draft fan draws the air across the wetted fill and expels it through the top of the structure. The factors to be considered in sizing a cooling tower are the heat load, approach temperature and wet bulb temperature. The heat load in determined by the process duty, the local climate determines the wet bulb temperature and the remaining factor, approach temperature, is determined by how low the water has to be. The driving force for heat transfer is the difference in enthalpy between the air contacting the water surface and the bulk air stream. The enthalpy content of moist air is the summation of the sensible heat content of both the water and air present, the latent heat of the water vapour, plus (for non-saturated mixtures) the superheat of the water vapour. At a given temperature, air is capable of co-existing with only a limited quantity of water vapour, the amount being determined by the partial vapour pressure of the water vapour in the mixture. If the pressure of the vapour in the air is lower than the atmospheric pressure then evaporation can take place.

\section{Wet Bulb Temperature:}

The air would have to be cooled in order to reach $100 \%$ saturation with moisture. The design wet bulb temperature is determined by the geographical location. Usually the design wet bulb temperature selected is not exceeded over 5 percent of the time in that area. Wet bulb temperature is a factor in cooling tower selection; the higher the wet bulb temperature, the smaller the tower required to give a specified approach to the wet bulb at a constant range and flow rate.

\section{Approach Temperature:}

The difference between the required cooled water temperature and the wet bulb temperature; determines how difficult the duty is. A small approach means a larger cooling tower as shown in the figure- 3 .

\section{Heat load:}

A function of the quantity of water to be cooled and cooling range. For a fixed heat load, various combinations of range and approach will be possible; the graph in Figure-8 Shows the effect on tower size. A large range and small flow results in a smaller cooling tower. The heat load calculation as shown in the table No.4.A cooling tower cools the water by using a combination of heat and mass transfer. The entering water is distributed through the tower via spray nozzles over plastic fill packing, which provides a large water surface area to be exposed to ambient air. The ambient air can be circulated naturally using available wind currents, or using mechanical fans (a mechanical draught tower is far more dependable as it uses a known volume of air, as opposed to natural draught which is generally used on large hyperbolic towers for electricity generation). Most of the heat is transferred to the air through evaporation of a portion of the circulating water (approximately $1 \%$ for every $8^{\circ} \mathrm{C}$ range), the remainder through sensible heat transfer. The difference in temperature between the water entering and leaving the cooling tower is known as the cooling range. Accordingly, the range is determined by the cooling tower heat load imposed by process and water flow rate, not by the size or capability of the cooling tower 


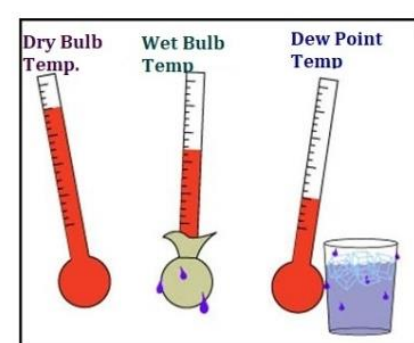

The dry bulb Temperature is the air temperature measured using a standard Theemometer. It is the temperature reported in daily weather forcasts and is sometimes referred as the ambient air temperature.

Wet Bulb Temperature

The wet bulb temperature with a standard thermometer and a wet piece of cloth covers the bulb of the thermometer. As air passes over the wet cloth, the water in the cloth evaporate, drawing heat out of the thermometer.

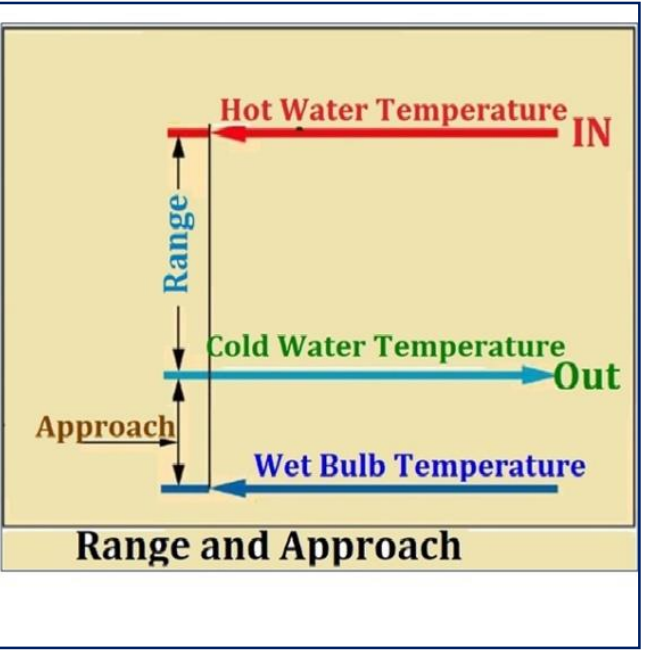

Fig- 3

\section{PERFORMANCE GUARANTEE TEST COOLING TOWER}

The purpose of this test procedure was to prescribe uniform methods and instrumentation for all conditions and measurements involved in determining tower - cooling performance. Cooling Tower Fans. The purpose of a cooling tower fan is to move a specified quantity of air through the system, overcoming the system resistance which is defined as the pressure loss. The product of air flow and the pressure loss is air power developed/work done by the fan; this may be also termed as fan output and input $\mathrm{kW}$ depends on fan efficiency. The fan efficiency in turn is greatly dependent on the profile of the blade. An aerodynamic profile with optimum twist, taper and higher coefficient of lift to coefficient of drop ratio can provide the fan total efficiency as high as 85-92 \% as shown in the performance curve figure No.-4. However, this efficiency is drastically affected by the factors such as tip clearance, obstacles to airflow and inlet shape, etc. As the metallic fans are manufactured by adopting either extrusion or casting process it is always difficult to generate the ideal aerodynamic profiles. The FRP blades are normally hand moulded which facilitates the generation of optimum aerodynamic profile to meet specific duty condition more efficiently. Cases reported where replacement of metallic or Glass fibre reinforced plastic fan blades have been replaced by efficient hollow FRP blades, with resultant fan energy savings of the order of 20-30\% and with simple payback period of 6 to 7 months. Also, due to lightweight, FRP fans need low starting torque resulting in use of lower HP motors. The lightweight of the fans also increases the life of the gear box, motor and bearing is and allows for easy handling and maintenance.

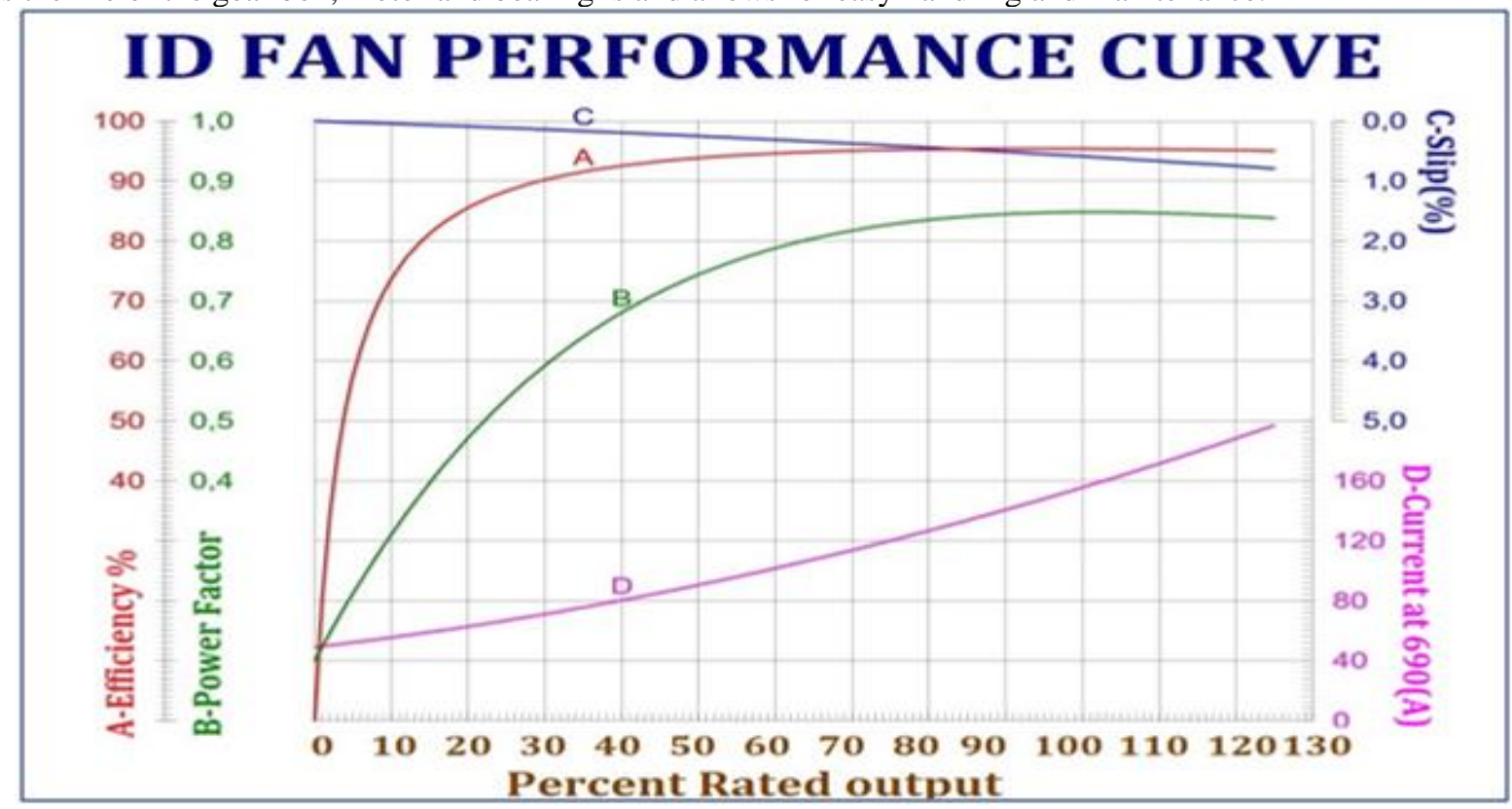

Fig-4

\section{CONDUCT OF TEST:}

The test was conducted by accredited representatives of the M/S. Paharpur and the Dangote Executives.. The test was done with performance guarantee, it was desirable for representatives of both the M/S. Paharpur and the Dangote were present at the time the test performed. In these cases the manufacturer has the right to inspect the tower in advance to see whether tower was ready 
for test. Such representatives were the freedom to witness all phases of the test data collection Test was conducted in the July August 2020 months. Following structural completion of the tower. Towers with PVC film fills was operated at design water flow and heat load for 1000 hours prior to doing a performance test. The reason for this is to wash lubricants, if any, from the surface of the fill.

Performance Assessment of Cooling Towers

In operational performance assessment, the typical measurements and observations involved are:

1. Cooling tower design data and curves to be referred to as the basis.

2. Intake air WBT and DBT at each cell at ground level using a whirling pyschrometer.

3. Exhaust air WBT and DBT at each cell using a whirling psychrometer.

4. CW inlet temperature at risers or top of tower, using accurate mercury in glass or a digital thermometer.

5. CW outlet temperature at full bottom, using accurate mercury in glass or a digital thermometer.

6. Process data on heat exchangers, loads on line or power plant control room readings, as relevant.

7. CW flow measurements either direct or inferred from pump motor $\mathrm{kW}$ and pump head and flow characteristics.

8. CT fan motor amps, volts, $\mathrm{kW}$ and blade angle settings.

9. TDS of cooling water.

10. Rated cycles of concentration at the site conditions.

\section{CONDITION OF EQUIPMENT:}

At the time of test the equipment was in good condition with particular attention to the following :

1. Water distribution system was clear and free of foreign materials which may clog or impede the normal water flow.

2. Mechanical equipment was in good working order, with fans adjusted for proper rotation and uniform angle that will yield within $+/-10 \%$ of the specified horsepower loading.

3. Drift eliminators was clear and free of algae and other deposits which may impede normal air flow.

4. Filling was free of foreign materials such as oil, tar scale or algae.

5. Water level in cold water basin was at normal operating elevation and maintained substantially constant during the test.

The test was conducted within the following limitations:

\section{OPERATING CONDITIONS:}

1. The wet bulb temperature was in accordance with wet bulb temperature and measured with mechanically aspirated psychomotor. The thermometer was not having least count more than $0.1^{\circ} \mathrm{C}$. The wick cleaned and continuously supplied with distilled water at temperature close to the prevailing wet bulb temperature.

2. The average wind velocity was $18 \mathrm{~km} / \mathrm{hr}$. Wind velocity measurement was made with an anemometer. Measurement made in an open and un-obstructed location within 100 feet of and to windward of the tower.

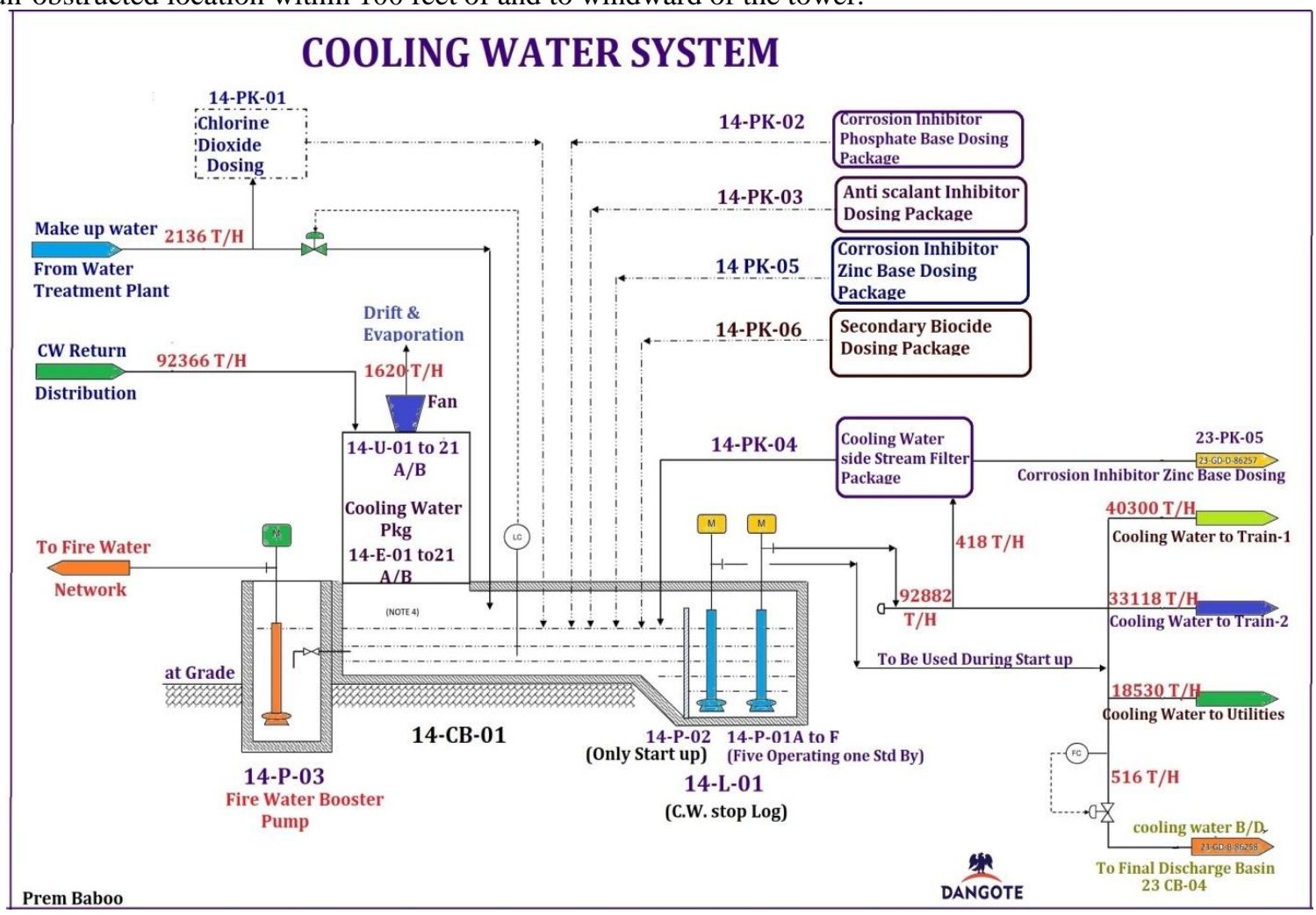

Fig-5 
The following variations from the design conditions is permissible:

1. Wet Bulb Temperature was not more than $8.3{ }^{\circ} \mathrm{C}$ above or below design wet bulb temperature.

2. Range not more than $20 \%$ below or above as per figure No.- 6

3. The circulating water flow was not more than $10 \%$ above or below the design circulating water flow. In the case of multi-cell tower were permissible to shut down one or more cells.

4. The water was distributed to all operating cells and/or parts of the tower as recommended by the M/S. Paharpur.

5. The total dissolved solids in the circulating water as determined by evaporation were not exceeding the $5000 \mathrm{ppm}$.

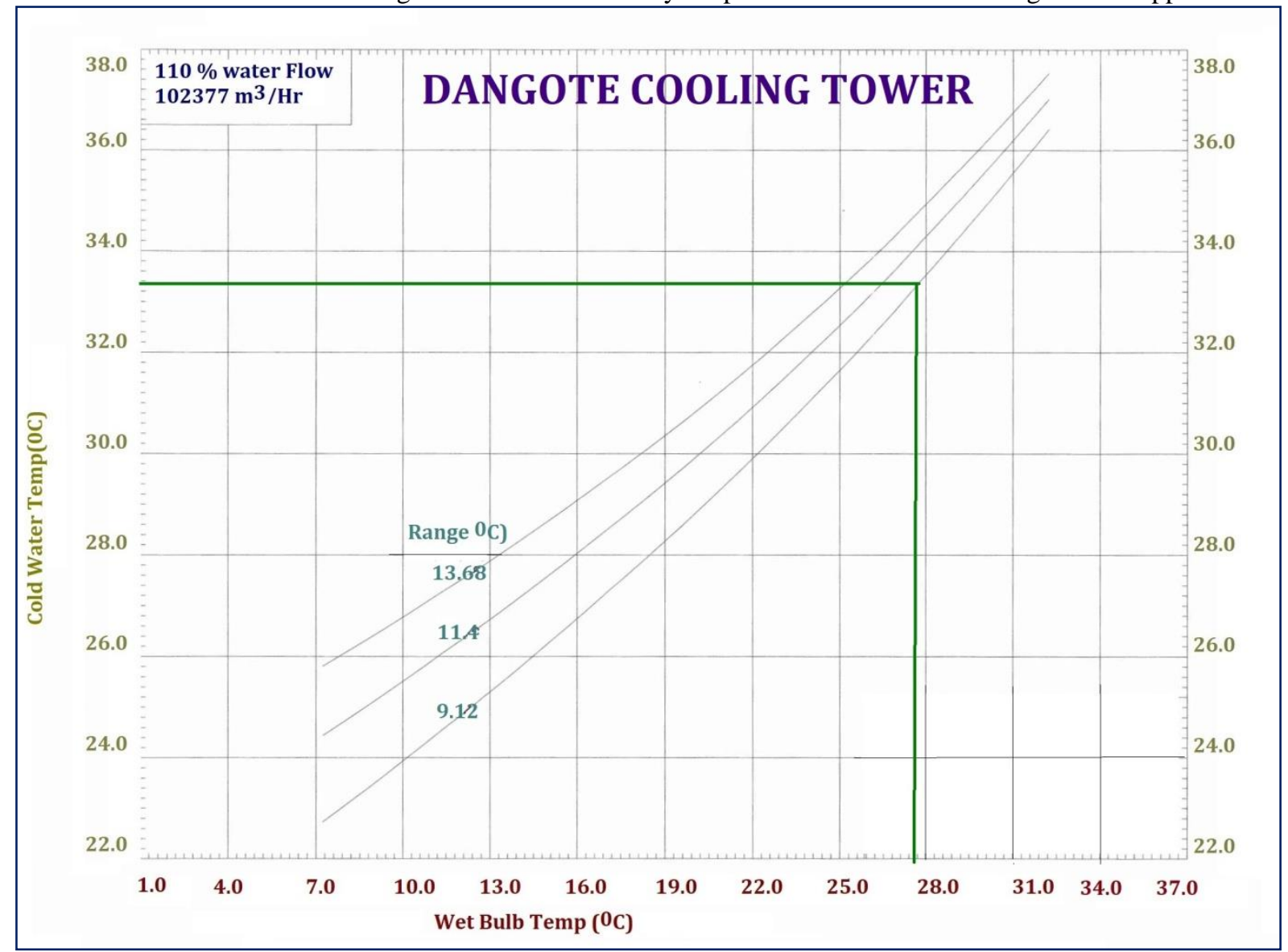

Fig-6

Duration of Test and Readings:

After reaching steady state conditions the duration of the test was done for one hour. If the thermal lag time is more than 5 minutes then the testing duration should be done at least one hour plus thermal lag time. Thermal lag time is calculated by using the following formula before start of test.

\section{Thermal lag time in minutes $=$}

Volume of water in the basin in $\mathrm{m}^{3} /$ Test water flow rate in $\mathrm{m}^{3} /$ Minute

Hence Thermal Lag Time=7710/1524=5.05 Min.

Hence the test carried out for one hour.

Reading taken as following table No.-3

\begin{tabular}{|c|c|c|c|c|c|c|c|c|c|}
\hline \multirow{2}{*}{$\begin{array}{l}\text { Sr. } \\
\text { No. }\end{array}$} & \multirow[t]{2}{*}{ Measurments } & \multicolumn{7}{|c|}{ Time } & \multirow{2}{*}{$\begin{array}{l}\text { Units } \\
{ }^{0} \mathrm{C}\end{array}$} \\
\hline & & 10.00 & 12.00 & 14.00 & 16.00 & 18.00 & 20.00 & 22.00 & \\
\hline 1 & Wet Bulb Temperature & 24.8 & 25.2 & 25.9 & 25.8 & 25.4 & 25.0 & 24.2 & ${ }^{0} \mathrm{C}$ \\
\hline 2 & Cold water temp & 30.3 & 31.5 & 32.2 & 32.1 & 31.7 & 31.3 & 29.5 & ${ }^{0} \mathrm{C}$ \\
\hline 3 & Hot water Temp. & 39.8 & 41.2 & 42.1 & 42 & 41.3 & 41.0 & 40.6 & ${ }^{0} \mathrm{C}$ \\
\hline 4 & Circulating Water Flow & 90500 & 90600 & 90650 & 90640 & 90650 & 90640 & 90660 & $\mathrm{M}^{3} / \mathrm{hr}$ \\
\hline 5 & Fan drive power input & 138 & 137.4 & 138.1 & 137 & 136.6 & 137.1 & 135.3 & KW \\
\hline 6 & Wind velocity & 16.7 & 17.5 & 17.6 & 17.5 & 17.7 & 17.5 & 17.4 & $\mathrm{~m} / \mathrm{sec}$ \\
\hline
\end{tabular}




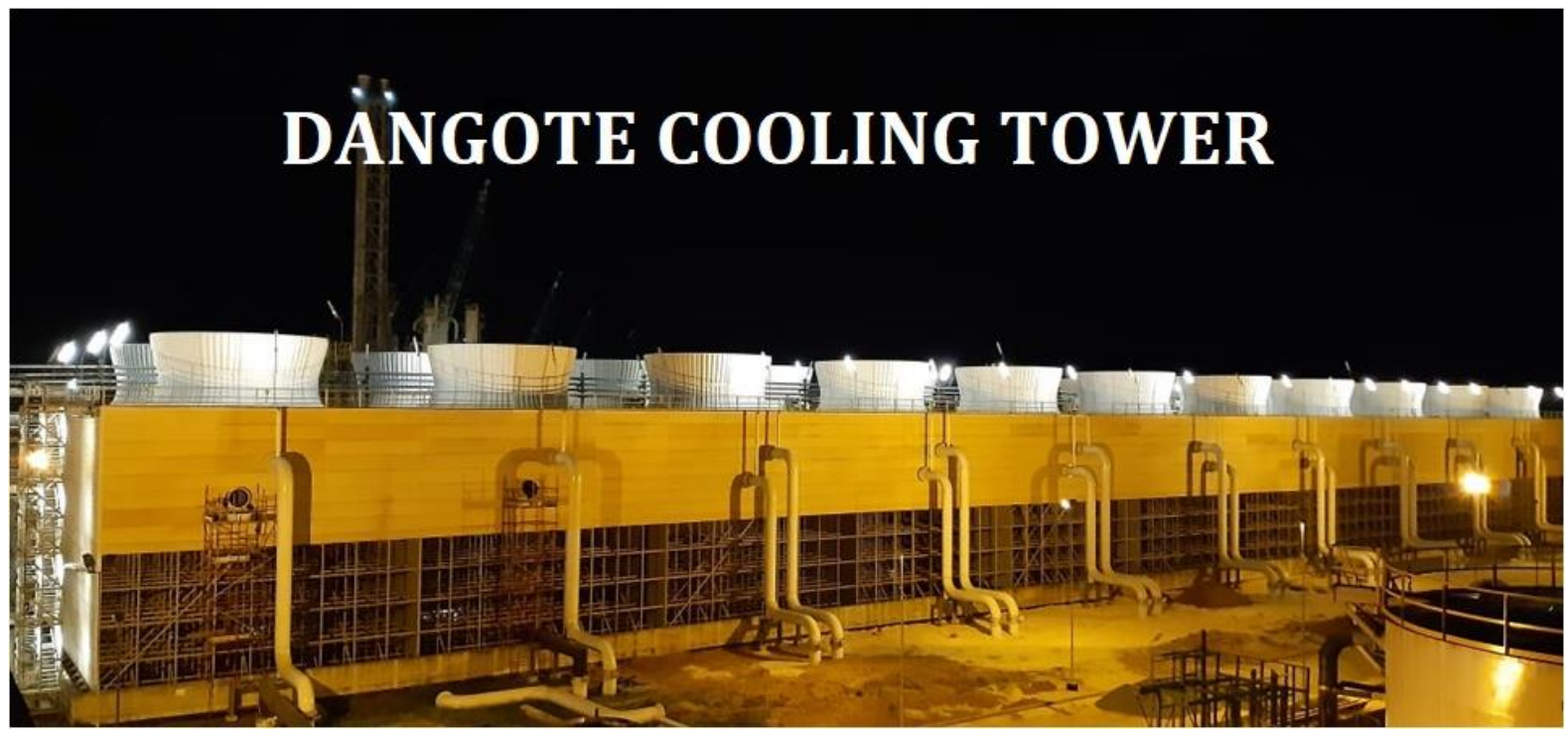

Fig-7

\begin{tabular}{|c|c|c|c|c|c|}
\hline \multicolumn{6}{|c|}{ Cooling Tower Calculation } \\
\hline Sr.No. & \multirow{2}{*}{\multicolumn{3}{|c|}{$\begin{array}{l}\text { Observations } \\
\text { Inlet Cooling Water Temperature }\end{array}$}} & Value & Units \\
\hline 1 & & & & 42.5 & ${ }^{0} \mathrm{C}$ \\
\hline 2 & \multicolumn{3}{|c|}{ Outlet Cooling Water Temperature } & 33.3 & ${ }^{0} \mathrm{C}$ \\
\hline 3 & \multicolumn{3}{|c|}{ Air Wet Bulb Temperature near Cell } & 27.8 & ${ }^{0} \mathrm{C}$ \\
\hline 4 & \multicolumn{3}{|c|}{ Air Dry Bulb Temperature near Cell } & 39.3 & ${ }^{\circ} \mathrm{C}$ \\
\hline 5 & \multicolumn{3}{|c|}{ Number of CT Cells on line with water flow } & 22 & \\
\hline 6 & \multicolumn{3}{|c|}{ Total Measured Cooling Water Flow } & 93070 & $\mathrm{~m}^{3} / \mathrm{Hr}$ \\
\hline \multirow[t]{2}{*}{7} & \multicolumn{3}{|c|}{ Measured CT Fan Flow } & 93070 & $\mathrm{~m}^{3} / \mathrm{Hr}$ \\
\hline & \multicolumn{5}{|l|}{ Analysis } \\
\hline 1 & \multicolumn{3}{|c|}{ CT water Flow $/$ Cell, $\mathrm{m}^{3} / \mathrm{hr}$} & 4230.455 & $\mathrm{~m}^{3} / \mathrm{Hr}$ \\
\hline 2 & \multicolumn{3}{|c|}{ CT Fan air Flow, $\mathrm{m}^{3} / \mathrm{hr}$ (Avg.) per Cell } & 2281320 & $\mathrm{~m}^{3} / \mathrm{Hr}$ \\
\hline 3 & \multicolumn{3}{|c|}{ CT Fan air Flow kg/hr (Avg.) } & 2463826 & $\mathrm{Kg} / \mathrm{Hr}$ \\
\hline 4 & Density $\mathrm{kg} / \mathrm{m}^{3}$ & 1.08 & $\mathrm{~kg} / \mathrm{m}^{3}$ & & \\
\hline 5 & \multicolumn{3}{|l|}{ Fan static Efficiency } & 57.36 & $\%$ \\
\hline 6 & \multicolumn{3}{|l|}{ Fan Total Efficiency } & 80.22 & $\%$ \\
\hline 7 & \multicolumn{3}{|l|}{ CT Range } & 9.2 & ${ }^{0} \mathrm{C}$ \\
\hline 8 & \multicolumn{3}{|l|}{ CT Approach } & 5.5 & ${ }^{0} \mathrm{C}$ \\
\hline 9 & \multicolumn{3}{|c|}{$\%$ CT Effectiveness $\{$ (range/(Approach+ range) $\}$} & $62.59 \%$ & $\%$ \\
\hline 10 & \multicolumn{3}{|c|}{ Cooling Duty per Cell(flow rate $*$ range* 1000$)$} & 38920182 & $\mathrm{~K} . \mathrm{Cal} / \mathrm{Hr}$ \\
\hline 11 & \multicolumn{3}{|c|}{ Evaporation Loss/Cell $(.00085 * 1.8 *$ flow $(\mathrm{T} 2+\mathrm{T} 1)$} & 59.548 & $\mathrm{~m}^{3} / \mathrm{hr} /$ Cell \\
\hline 12 & \multicolumn{3}{|c|}{$\begin{array}{l}\text { Percentage Evaporation Loss }\left\{\left(.00085^{*} 1.8 * \mathrm{CW} \text { flow*(T2- }\right.\right. \\
\text { T1) }\} / \text { C.W.Flow }\end{array}$} & $1.41 \%$ & $\%$ \\
\hline 13 & Blow down requirement & $\mathrm{COC}$ & 5.8 & 12.406 & $\mathrm{~m}^{3} / \mathrm{hr} /$ Cell \\
\hline 14 & \multicolumn{3}{|c|}{ Makeup water requirements(Eva. loss+ B/D) } & 71.954 & $\mathrm{~m}^{3} / \mathrm{hr} /$ Cell \\
\hline 15 & \multicolumn{3}{|c|}{ Total Makeup water requirements, 22 cell } & 1582.981 & $\mathrm{~m}^{3} / \mathrm{hr}$ \\
\hline
\end{tabular}

Table-4

The thumps rule of evaporation loss in the cooling tower is $\left(\mathrm{m}^{3} / \mathrm{hr}\right)=0.00085^{*} 1.8^{*}$ Circulation rate $\left(\mathrm{m}^{3} / \mathrm{hr}\right)^{*}(\mathrm{~T} 2-\mathrm{T} 1)$, where T1Cold water temperature and T2 is hot water temperature. The evaporation loss is the water quantity evaporated for the cooling duty and theoretically for every 1000000 K.Cal heat rejected evaporation quantity works out to $1.8 \mathrm{~m}^{3}$. 

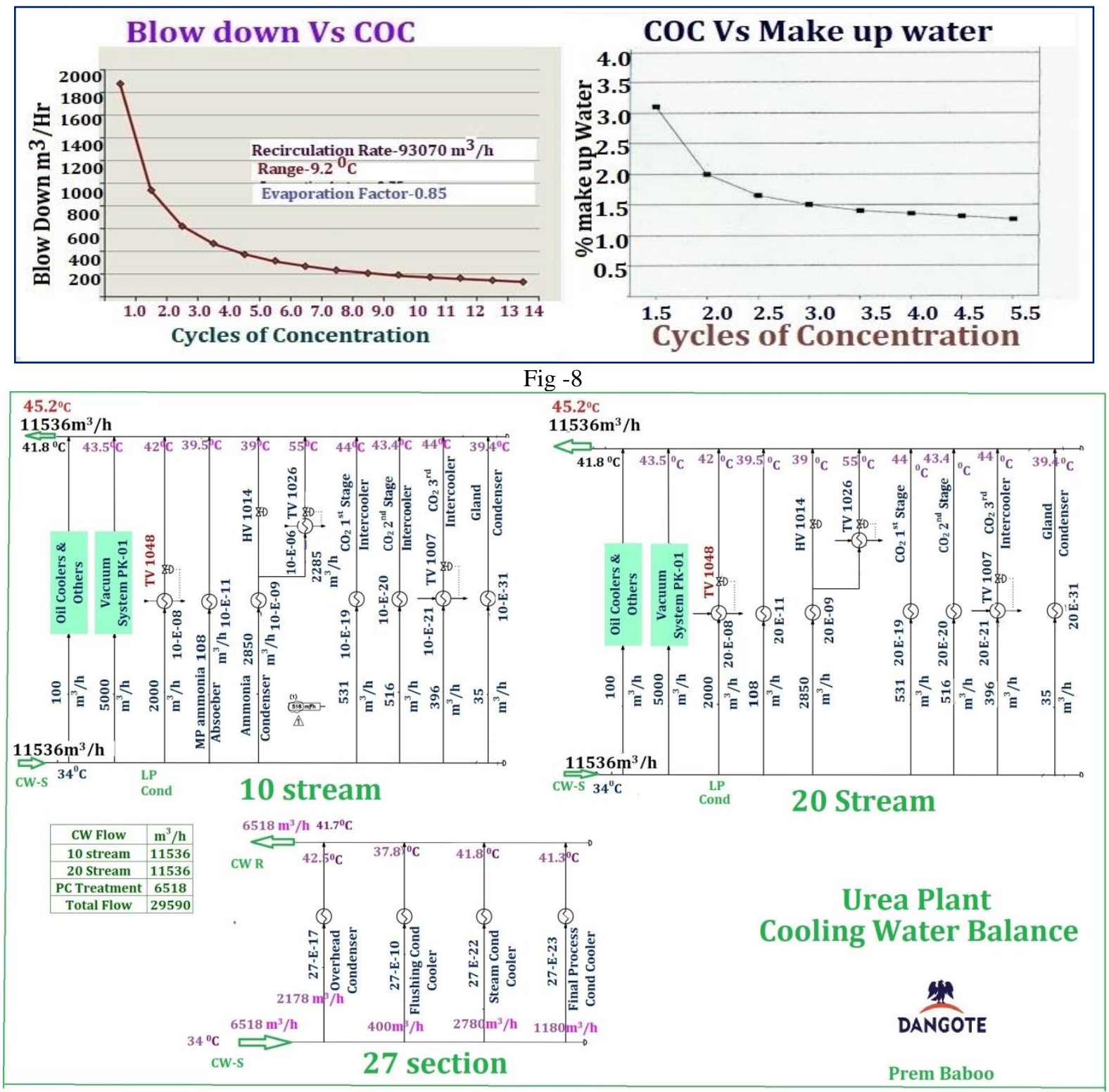

Fig-9

\section{CONCLUSION}

On the basis of above-mentioned design parameters, the energy saving through cooling tower using better packing and chemically treated water and maintained COC, Additionally, the lower recirculation water flow rate and its higher temperature will benefit the heat transfer process in the cooling tower, further reducing operating costs. By introducing additional air coolers, besides reducing operating costs, fresh water consumption can also be reduced. The studies on cooling towers have been carried out on various aspects of cooling towers aimed at optimizing the operation. A suitable water distribution across the plane area of the cooling tower can increase efficiency of induced draft cooling towers. The deterioration of filling material is one of the concerns. Proper shutdown strategy can save the manpower. It was observed that vertical orientation of packing increases performance, inlet conditions of flow rate of water, air and inlet water temperature are important factors for cooling tower operations.

\section{REFERENCES}

[1] A Review Study On Cooling Towers; Types, Performance and Application, XI. International Conference on Nuclear Structure Properties (NSP2018), Trabzon-TURKEY, 12-14 September 2018,by Faraz Afshari1 , Heydar Dehghanpour.

[2] Evaporative cooling of water in a mechanical draft cooling tower S.P. Fisenko .A.A. Brin, A.I. Petruchik, International Journal of Heat and Mass Transfer 47 (2004) 165-177.

[3] Design Modifications in Induced Draft Cooling Tower for Improved Efficiency by Agha Shahzaib Ali; Muhammad Ibtehaj Akhtar; Dr Ajmal Shah Department of Mechanical Engineering.

[4] Cooling Tower selection and sizing (Engineering Design Guid lines) by Viska Mulyandasari, KLM technology group.

Legends-COC- Cycles of concentration, CT-Cooling Tower, WBT-wet bulb temperature, DBT-Dry bulb temperature.ID-Induced draught, 